\title{
Penerapan Mass Customization Perancangan Produk Berbasis Ergonomi
}

\author{
Muhamad Abdul Jumali \\ Program Studi Teknik Industri \\ Fakultas Teknologi Industri \\ Universitas PGRI Adi Buana Surabaya \\ Email : m_abdul_jumali@ymail.com
}

\begin{abstract}
Abstrak
Dalam aktivitasnya, manusia menggunakan berbagai macam produk dalam berinteraksi dan melibatkan panca indra, mekanisme pengambilan keputusan oleh otak serta menghasilkan gerakan-gerakan oleh otot-otot tangan dan kaki. Produk yang digunakan idealnya memiliki nilai ergonomi dimana setiap perancangannya memperhatikan karakteristik manusia sebagai objek penggunanya, karena manusia memiliki keterbatasan dalam menggunakan maupun penggunaanya. Penerapan mass customization dalam perancangan produk bertujuan untuk mendapatkan variasi jenis sesuai keinginan dan kebutuhan dari customers sebagai pelanggan.
\end{abstract}

Kata Kunci : customers, ergonomi, mass customization, produk

\section{PENDAHULUAN}

Pada kehidupan sehari-hari setiap kegiatan yang dilakukan manusia banyak menggunakan berbagai macam jenis produk, alat, mesin maupun fasilitas kerja yang lain. Dalam aktivitas penggunaan produk tersebut, manusia melibatkan panca indra yang dimilikinya, sebagai mekanisme pengambilan keputusan dilakukan oleh otak dan otot - otot tangan kaki digunakan untuk melakukan gerakan kerja yang dihasilkan (Selladurai, R. 2004)

Pengadaan produk dalam sistem produksi yang dulu dikembangkan melalui konsep produksi massal (mass - production) dengan berdasarkan pada pembuatan produk-produk standar, cenderung kemudian harus ditata kembali secara fleksibel dan responsif ke upaya pemenuhan kepuasan pelanggan yang sangat beragam (mass - customization) dengan pasar yang lebih luas (mass-marketing) (Wignjosoebroto, Sritomo, 2006). Dimana konsep mass production adalah kunci strategi manufaktur dalam memproduksi produk dan jasa yang lebih efisien dan sangat hemat biaya. Sistem Mass production dikarakteristikan kemampuannya untuk memproduksi dengan jumlah yang sangat banyak melalui standar produk - produk dengan biaya rendah (low cost), melalui operasi yang berulang dan aliran produksi yang panjang (Hsiao, S.-wen, et al 2010). Sedangkan mass customization merupakan suatu proses pengadaan produk yang lebih fleksibel dengan menyediakan produk atau jasa yang lebih bervariasi melalui pendekatan pelanggan dan biaya sistem mass production.

\section{TINJAUAN PUSTAKA}

\section{A. Mass Costomization Kunci Keberhasilan Dalam Sistem Produksi Saat Ini}

Mass Customization mengacu pada proses produksi barang dan jasa disesuaikan dengan kebutuhan customer sebagai pelanggan di pasar massal. Mass customization merupakan proses yang memindahkan mass production sebagai metode utama yang digunakan pada fasilitas produksi. Sebagian besar studi tentang mass customization muncul untuk dikembangkan dari perspektif manajemen strategis (Charu Chandra,et al,)

Mass customization adalah suatu proses dimana aspek organisasi, proses produksi, serta teknologi dirancang untuk menyediakan produk-produk sesuai dengan keinginan dan kebutuhan customer sebagai pelanggan.

Empat pendekatan yang digunakan dalam standarisasi mass customization ialah standarisasi komponen, standarisasi proses, standarisasi produk, dan standarisasi pengadaan. Metode mass customization bisa dikatakan berhasil jika memenuhi empat standarisasi tersebut. Suatu perusahaan yang telah menerapkan standarisasi mass customization yaitu "Dell Computer", dimana customer sebagai pelanggan dapat menentukan sistem komputer yang diinginkan dengan memperhatikan customization standard sebagai contoh pelanggan dapat memilih beberapa prosesor mulai dari 1,4 sampai $1,7 \mathrm{GHz}$; beberapa pilihan memori mulai dari $512 \mathrm{MB}$ sampai 2 GB; atau video card dari $32 \mathrm{MB}$. Dell Computer menawarkan pilihan dangan perbedaan harga yang spesifik sehingga customer sebagai pelanggan dapat memilih sesuai dengan keinginan dan 
kebutuhan mereka. Mass customization standard juga banyak diterapkan pada produk - produk seperti printer dan mobil (Charu Chandra,et al,)

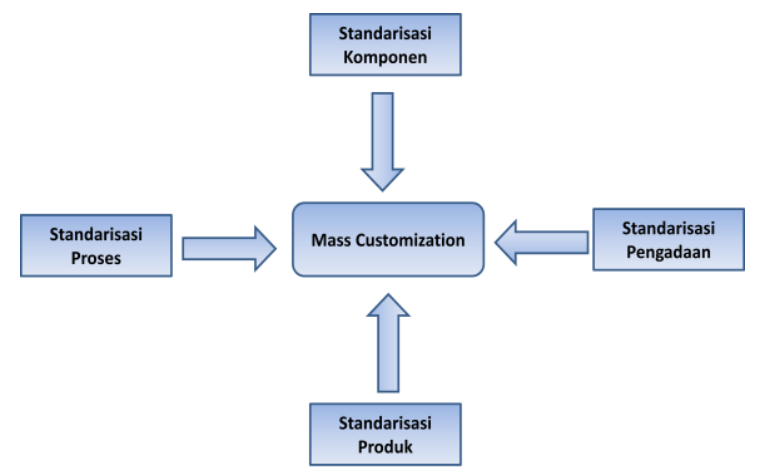

Gambar 1. Mass Customization Standard Method

Kesuksessan mass customization system tergantung pada beberapa faktor penting yaitu sensitifitas customer sebagai pelanggan, proses tanggungan, lingkungan yang kompetitif, dan kesiapan keorganisasian (Hsiao, S.-wen, 2010). Sensitifitas pelanggan menggambarkan bahwa permintaan pelanggan terhadap produk bertujuan untuk mencapai kesuksesan mass customization system. Hal ini tergantung dari besarnya pengorbanan pelanggan untuk membuat produk customize dan kemampuan perusahaan dalam mewujudkan produk sesuai spesifikasi customer sebgai pelanggan, dalam waktu dan biaya yang wajar / normal. Keseimbangan antara keduanya merupakan faktor penentu keberhasilan mass customization dalam pengadaan produk. Tanggungan proses dimana perusahaan harus memiliki akses informasi mengenai kebutuhan individu pelanggan dan selanjutnya diproses dalam sistem produksi. Kondisi pasar dengan lingkungan yang kompetitif sangat mempengaruhi mass customization system. Waktu yang potensial adalah saat kebutuhan customer sebagai pelanggan sesuai dengan kapasitas produksi dan variasi produk yang banyak. Struktur organisasi memiliki peran dalam mendukung generasi pengetahuan dan pemanfaatan efisiensi. Mass customization juga membutuhkan perubahan organisasi ditingkat penjualan (Selling).

\section{B. Perancangan Produk Berbasis Ergonomi}

Definisi dan pengertian yang bermacam-macam tergantung perspektif yang ada; ergonomi secara umum telah diartikan sebagai "the study of work" (ergo = kerja, nomos = hokum / aturan) dan mampu membawa perubahan yang signifikan dalam mengimplementasikan konsep peningkatan produktivitas melalui efisiensi serta efektifitas penggunaan tenaga kerja dan pembagian kerja berdasarkan karakteristik kelebihan maupun kekurangan manusia (Wignjosoebroto, Sritomo, 2006)

Banyak istilah maupun definisi yang terkait dengan pemahaman mengenai ergonomi seperti human factors, ergonomics, human engineering, human factors psychology, applied ergonomics dan industrial engineering / ergonomics. Dari banyak istilah - istilah tersebut yang sering digunakan adalah human factors dan ergonomics. Pemahaman mengenai human factors berkaitan dengan permassalahan psikologi kerja (mental work loads dan cognitives issues); sedangkan ergonomi sendiri dikaitkan dengan physical works.

Dalam perancangan produk hendaknya memperhatikan segala keterbatasan manusia dalam hal kepekaan panca indra, kecepatan, ketepatan dalam proses pengambilan keputusan, kemampuan penggunaan sistem gerakan otot, dimensi ukuran tubuh (anthropometri), dan sebagainya; yang kemudian menggunakan semua informasi mengenai faktor - faktor manusia (human factors) sebagai acuan dalam menghasikan sebuah rancangan mesin atau produk yang serasi, selaras, dan seimbang dengan manusia yang mengoperasikannya nanti (Selladurai, R, 2004).

Pada era saat ini, dalam merancang suatu produk telah berpindah dari pendekatan yang berorientasi produksi massal pada masa lampau menjadi produksi yang berorientasi customer sebagai pelanggan dengan memperhatikan kondisi pasar yang ada yang dikenal dengan istilah mass customization. Pendekatan ini mampu meminimalkan resiko dan biaya pengembangan produk baru (Wignjosoebroto, Sritomo, 2006). 
Table 1. Produk Ergonomi

\begin{tabular}{|l|l|}
\hline \multicolumn{1}{|c|}{ Jenis Produk } & \multicolumn{1}{c|}{ Metode yang digunakan } \\
\hline Mobil & Mass Production \\
Makanan & Mass Production \\
Pakaian & Mass Customization \\
\hline
\end{tabular}

Namun fokus perhatian dalam perancangan produk berbasis ergonomis ialah setiap rancangan produk diproduksi berdasarkan kepentingan manusia sebagai penggunanya misalnya segi keselamatan, keamanan, serta kenyamanan. Sebuah kajian ergonomis jelas akan merujuk pada kepentingan manusia, tidak semata - mata mengarah pada aspek teknis - fungsional dari sebuah produk, mesin ataupun fasilitas kerja yang dirancang. Bilamana tidak ada unsur manusia yang terlibat dalam interaksi sistem rancangan produk seperti halnya dalam sistem mesin yang bekerja secara otomatis penuh (full - automatics) maka produk tersebut belum menerapkan nilai nilai ergonomis.

Pendekatan ergonomi dalam perancangan teknologi di industri telah menempatkan rancangan produk dan sistem kerja yang awalnya serba rasional - mekanistik menjadi tampak lebih manusiawi. Disini faktor yang terkait dengan fisik (faal / fisiologi) maupun perilaku (psikologi) manusia baik secara individu pada saat berinteraksi dengan mesin dalam sebuah rancangan sistem manusia - mesin dan lingkungan kerja fisik akan dijadikan pertimbangan utama (Kotha Suresh, 1995).

\section{Tahapan Perancangan Produk}

Produk merupakan sebuak karya kreativitas manusia yang dapat dilihat, didengar, dirasakan serta diwujudkan untuk memenuhi kebutuhan fungsional tertentu dengan melalui suatu proses yang panjang. Produk dapat berupa benda fisik maupun non - fisik (jasa), bisa dalam bentuk yang komplek seperti mesin maupun fasilitas kerja, dan bisa pula merupakan barang konsumtif sederhana untuk keperluan sehari - hari. Untuk menghasilkan suatu produk yang berskala industri dan memiliki nilai komersial diperlukan beberapa tahap yakni:

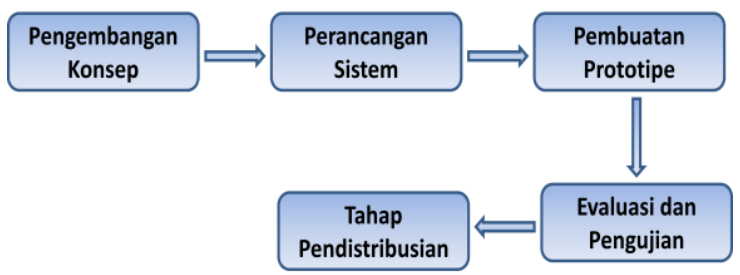

Gambar 2. Tahapan Perancangan Produk

Aktivitas perancangan produk pada umumnya diawali dengan tahapan identifikasi dan formulasi tentang segala potensi teknologi, baik berupa teknologi produk maupun teknologi proses, yang dimiliki serta target pasar yang ingin dipuaskan. Selanjutnya diperlukan penyusunan sebuah konsep produk dapat berupa produk baru maupun produk lama yang akan dimodifikasikan menjadi sebuah produk yang mencoba mewujudkan ide ataupun gagasan yang masih bersifat abstraktif menjadi sebuah rancangan (system \& detail design) yang mampu memberikan gambaran lebih jelas mengenai bentuk maupun penampilan yang diinginkan untuk memenuhi kebutuhan pasar (demand pull) atau dilatar - belakangi oleh dorongan inovasi teknologi (market push) (Selladurai, R, 2004).

\section{Modularity Perancangan Produk}

Modularity product design adalah suatu konsep product design yang berkaitan erat dengan pendekatan mass customization dan postponement strategic. Modularity product design memiliki pengertian mengembangkan suatu produk dengan cara membagi produk tersebut menjadi beberapa komponen atau modul yang saling independent. Hal ini dimaksudkan agar komponen komponen tersebut dapat dirakit atau digabungkan dengan berbagai cara untuk menghasilkan beberapa variasi produk yang berbeda antara satu dengan lainnya. Suatu produk dapat dikatakan modular tegantung pada kesamaan fungsi dan desain fisik. Komponen - komponen yang memiliki kesamaan dalam fungsi dan desain fisik ini biasa disebut sebagai common component. 
Modularity product design dapat meningkatkan variasi dari produk namun dilain sisi juga mengakibatkan delivery time menjadi lebih pendek. Selain itu modularity product design juga memiliki keuntungan dalam menurunkan biaya produksi (Kotha Suresh, 1995).

Untuk dapat melakukan modularity product design maka perusahaan harus memenuhi beberapa ketentuan sebagai berikut :

- Kesiapan akan kebutuhan input ketika dibutuhkan seperti pekerja yang memiliki skill dan kemmpuan yang memenuhi kualifikasi teknik dalam melakukan modularity product design.

- Standarisasi produk yang tinggi. Artinya komponen yang dapat digunakan bersama sama atau yang memiliki tingkat communality terdapat pada sebagian besar komponen penyusun produk.

\section{KESIMPULAN}

Pendekatan ergonomi yang dilakukan dalam perancangan produk pada lantai produksi akan mampu menghasilkan sebuah rancangan produk yang sesuai dengan ekspektasi manusia pekerja atau tanpa menyebabkan beban kerja yang melebihi ambang batas (fisik maupun psikologis) manusia untuk menahannya. Mass customization method dalam perancangan produk bertujuan untuk memberikan variasi sesuai dengan keinginan dan kebutuhan yang diharapkan pelanggan berdasarkan kondisi pasar industri.

Penerapan mass customization di banyak perusahaan besar menjadi trend industri saat ini, hal ini karena mass customization berpengaruh terhadap kinerja dan keberhasilan secara keseluruhan perusahaan. Mass customization akan terus mendominasi sistem produksi dan operasi menajemen di masa depan. Perusahaan yang telah menerapkan mass customization, menjadi sesuatu strategi kepentingan yang penting. Mass customization dapat mengidentifikasi kebutuhan individual mass customization, ketika reusability mencapai maksimum dalam rangka mempertahankan biaya produksi yang rendah. Makalah ini menyajikan atribut kunci dan faktor faktor yang diperlukan untuk implementasi sistem tersebut. Beberapa strategi untuk menerapkan mass customization dieksplorasi. Beberapa aplikasi industri juga memperkenalkannya pada pemesanan dalam rangka meningkatkan pemahaman dan implikasi penggambaran praktis dari mass customization.

\section{DAFTAR PUSTAKA}

Charu Chandra, Grabis Jānis, "Managing Logistics For Mass Customization : The New Production Frontier". (n.d.). Knowledge Creation Diffusion Utilization, 335-340.

Hsiao, S.-wen, Chiu, F.-yuan, \& Lu, S.-hong. (2010). International Journal of Industrial Ergonomics Product-form design model based on genetic algorithms. International Journal of Industrial Ergonomics, 40(3), 237-246. Elsevier Ltd.

Kotha Suresh. (1995). Mass Customization : Implementing the Emerging Paradigm for Competitive Advantage. Strategic Management Journal, Vol.16 Special Issue : Technological Transformation and the New Compotitive Landscape, pp. 21 - 42. Jhon Wiley \& Sons.

Selladurai, R. (2004). Mass customization in operations management: oxymoron or reality? Omega, 32(4), 295-300.

Wignjosoebroto, Sritomo (2000). Evaluasi Ergonomis Dalam Proses Perancangan Produk Keynote address dalam Seminar Nasional Ergonomi 2000 yang diselenggarakan oleh Laboratorium Ergonomi \& Perancangan Sistem Kerja Jurusan Teknik Industri FTI-ITS dan Perhimpunan Ergonomi Indonesia (PEI) pada tanggal 20 Agustus 2000 di Hotel Sahid Surabaya

Wignjosoebroto, Sritomo (2006). Aplikasi Ergonomi dalam Peningkatan Produktivitas dan Kualitas Kerja di Industri. Keynote Seminar Nasional Ergonomi \& K3 - "Peranan Ergonomi dan K3 untuk Meningkatkan Produktivitas dan Kualitas Kerja" yang diselenggarakan oleh Perhimpunan Ergonomi Indonesia dan Laboratorium Ergonomi \& Perancangan Sistem Kerja Jurusan Teknik Industri FTI-ITS, tanggal 29 Juli 2006 di Kampus ITS, Sukolilo-Surabaya. 